\title{
Organizational Commitment and Job Satisfaction in the Hotel Industry: A Case Study in KSA Hotels
}

\author{
Mohamed Adel Mohamed Samy Mohsen \\ Lecturer, Faculty of Tourism and Hotels, Minia University
}

\begin{abstract}
Organizational commitment is defined as a psychological state that binds an employee to an organization. There are three main forms of Organizational commitment: affective, continuance, and normative. It has been linked to several issues related to the employee such as job satisfaction and turnover. There are a limited number of empirical studies that link organizational commitment to job satisfaction in Middle East hotels. Therefore, the purpose of this study is to explore organizational commitment of employees in Saudi hotels and its relation to their job satisfaction. The study aims to examine the three forms of organizational commitment with job satisfaction. The study used LaMastro's (1999) instrument to measure organizational commitment, and the Minnesota Satisfaction Questionnaire (MSQ) to measure job satisfaction. This paper is part of a project that was conducted in three five-star hotels in Saudi Arabia. Out of 900 forms distributed, 528 forms were successfully filled out. The study found that Affective Organizational Commitment is the most significant form of job satisfaction.
\end{abstract}

Key Words: Organizational commitment, job satisfaction, Affective, Continuance, Normative, Turnover

\section{Introduction}

Organizational commitment is referred to the psychological state that binds an employee to his/her employer (Allen and Meyer, 1990). According to Avolio et al. (2007), Organizational commitment is correlated with psychological empowerment. However, no empirical evidence of studies focusing on the relation between organizational commitment and job satisfaction in the hotel industry in the Middle East was found.

The purpose of this study is to explore organizational commitment of employees in Saudi hotels and its relation to their job satisfaction. The study aims to examine the three forms of organizational commitment with job satisfaction in order to identify which form is more significant to the achievement of employee job satisfaction. The study utilized LaMastro's (1999) instrument to measure organizational commitment. The study also used the Minnesota Satisfaction Questionnaire (MSQ) to measure job satisfaction.

This paper is part of a project that was conducted in three hotels in Saudi Arabia. This study is the first empirical study that focuses on organizational commitment and job satisfaction of hotel employees in the Middle East using the three forms of organizational commitment. It contributes to the literature and methodology of both organizational commitment and job satisfaction.

\section{Literature Review}

The term commitment generally refers to antecedents and consequences, as well as the process of becoming attached and the state of attachment itself (O'Reilly and Chatman, 1986). Organizational commitment has been defined as a psychological state that binds an employee to an organization (McMahon, 2007), thereby affecting attitudes toward the organization (Hallberg and Schaufeli, 2006). It is also defined as a mindset that takes different forms and binds an individual to a course of action that is of relevance to a particular target (Meyer \& Herscovitch, 2001). It is characterized by a strong belief in and acceptance of the organization's goals and values; a willingness to exert considerable effort on behalf of the organization; and a strong desire to maintain membership in the organization (Mowday et al., 1982).

According to McMahon (2007), there are three main forms of Organizational commitment: affective, continuance, and normative. Affective commitment refers to the degree to which a person identifies with, is involved in, and enjoys membership in an organization. Employees with effective commitment want to remain with an organization. It is strongly correlated with positive work-related behaviors such as attendance, organizational citizenship behavior (Meyer, Stanley, Herscovitch, \& Topolnytsky, 2002). Continuance commitment involves a person's bond to an organization based on what it would cost that person to leave the company. Continuance commitment is said to occur when an employee remains with an organization largely out of need, whether due to lack of alternatives or costs associated with leaving, such as lost income, seniority or retirement benefits. Normative commitment involves a feeling of moral obligation to continue working for a particular organization. Normatively committed employees feel that they ought to remain with the organization (Meyer \& Allen, 1991).

Organizational commitment was found to be correlated with employee-related aspects that can affect job satisfaction such as job involvement, job performance, employee turnover, workforce diversities, and leadership. Several empirical studies found a significant positive correlation between organizational commitment and job involvement (Blau and Boal, 1989; Mathieu and Zajac, 1990; Huselid and Day, 1991; Meyer, et al., 2002; Hallberg and 
Schaufeli, 2006). Consequently, organizational commitment is positively correlated with job performance (Colquitt et al., 2001; Meyer, et al., 2002).

Another significant correlation was found with employee turnover. It was found that employees who were highly committed to the organization had no intention to leave their jobs and low rates of absenteeism. Consequently, turnover rates in these organizations were very low (O'Reilly and Chatman, 1986; Blau and Boal, 1987; Huselid and Day, 1991; Camp, 1994; Chang, 1999; Allen, 2001; Colquitt et al., 2001; Meyer, et al., 2002; Sturges, et al., 2005; Cole and Bruch, 2006; Hallberg and Schaufeli, 2006; Loi, et al., 2006). Continuance organizational commitment was the most significant form of related to employee turnover (Huselid and Day, 1991; Paré and Tremblay, 2007). However, the affective commitment was found to correlate negatively with absenteeism (Meyer, et al., 2002).

Organizational commitment was found to be correlated with workforce diversities. According to Mathieu and Zajac (1990), female employees are more committed to the organization than male employees. Married employees are more committed to the organization than non-married. Older employees are more committed to the organization than younger (Meyer and Allen, 1984; Mathieu and Zajac, 1990; Lok and Crawford, 1999). Healthy employees are more committed to the organization than unhealthy employees (Hallberg and Schaufeli, 2006). On the other hand, there was no correlation found between organizational commitment and job characteristics, salaries, Group cohesiveness (Mathieu and Zajac, 1990), years in the position, years of experience, or level of education (Lok and Crawford, 1999). Tenure, however, was found to be positively correlated with organizational commitment. Employees with more tenure (higher position) were significantly more committed to their organizations (Meyer and Allen, 1984; Mathieu and Zajac, 1990; Huselid and Day, 1991; Varona, 1996; Colquitt et al., 2001)

Organizational commitment was found to be correlated with several aspects of leadership. For instance, employees' organizational commitment increases as the efficiency level of leader communication increase as the work environment is enhanced (Mathieu and Zajac, 1990). According to Avolio et al. (2004), transformational leaders influence their followers' organizational commitment by motivating them to think critically, involving them in decision-making processes, and inspiring loyalty (Yammarino, Spangler, \& Bass, 1993; Bass \& Avolio, 1994; Avolio, 1999; Walumbwa \& Lawler, 2003; Lines, 2004). It is also found that strong leadership generates organizational commitment as loyalty to the leader is proved to be stronger than loyalty to organization (Chen et al., 2002)

The literature shows that the impact of organizational commitment on job satisfaction can be highly significant (Cook and Wall 1980; Lok and Crawford, 1999; Currivan, 2000; Allen, 2001) particularly affective organizational commitment (Meyer, et al., 2002). However, the majority of these studies were conducted in different industries on different employees (i.e. hospital nurses, school teachers, and factory workers). Very limited research has covered this area (linking organization commitment with job satisfaction) in the hospitality industry such as Smith et al. (1996). For instance, Bozeman and Perrewé (2001) and Gunlu et al. (2010) focused only on hotel managers; whereas nonmanagement (Rank and File) employees would normally have a different perspective. Lam et al. (2002) focused on employee turnover in the Hong Kong hotel industry. Kim et al. (2005) brushed on the topic focusing only on casual dining chains. Bai et al. (2006) conducted their case study in Las Vegas Hotel/Casino industry. Silva's (2006) study was conducted in Western US hotel chains without focusing directly on the relation between both organizational commitment and job satisfaction. Namasivayam and Zhao (2007) have investigated the impact of organizational commitment on several factors including Job satisfaction on Hospitality employees in India. None of the above studies used the same instruments that are used in this study to measure organizational commitment and job satisfaction. None of them were, therefore, correlating the three forms of organizational commitment with job satisfaction.

Oshagbemi (2000) has defined job satisfaction as "individual's positive emotional reaction to particular job". Job satisfaction relates to an attitude towards a job (Chen, C. F., 2006). It is a function of expectations of a certain job; if those expectations are fulfilled then satisfaction is accomplished (Bender et al, 2005). Evans (1997) believed that job satisfaction in terms of two constituents: job fulfillment and job comfort. Job fulfillment refers to one's assessment of how well the job is performed. Job comfort relates to the degree to which one is satisfied with the conditions of the job. Although wages were the thought to be the traditional source of job satisfaction (Bender et al, 2005; Bender and Heywood 2006; Chen, 2006; Kristensen and Johansson, 2008), some studies have found no correlation whatsoever between job satisfaction and wages (Allen 2001; Lalive, 2002; Böckerman and Ilmakunnas, 2006).

In terms of the relation with job performance, job satisfaction was found to be correlated significantly (Judge et al., 2001) in various aspects. For instance, job satisfaction and job performance were found to be positively and significantly related to both willingness and eagerness to share knowledge (De Vries, et al, 2006). A lower quality of leader-member exchange was associated with lower levels of in-role and innovative job performance, and with lower job satisfaction (Janssen and Van Yperen 2004). Individual psychological climate perceptions were found to have significant relationships with their job satisfaction, work attitudes, psychological well-being, motivation, and performance (Parker et al. 2003).

In terms of the relation with diversity management, several correlations have been empirically found. For instance, managers are found to be more satisfied than non-managers (Pitts, D. 2009). Married employees were found to be more satisfied than non-married ones. Healthy employees reported higher job satisfaction than unhealthy ones (Bender and 
Heywood 2006). Some studies found that gender and age were not affecting job satisfaction (Cummings et al 2008). However, other studies found the opposite. Men are found to be less satisfied than women (Bogler 2002; Bender et al, 2005; Böckerman and Ilmakunnas, 2006; Kristensen and Johansson, 2008; Pitts, D. 2009). This result has been explained that females have lower expectations about labor market outcomes. Therefore, they are more easily satisfied with their actual experience (Bender et al, 2005). Other studies have found that this is not the same case between fulltime and part-time jobs. Booth and Van Ours (2008) found that men have the highest working hours satisfaction if they work full-time without overtime hours. Women, on the other hand, prefer part-time jobs irrespective of whether these are small or large. They also found that women without children do not care about their hours of work at all while women with children are significantly happier if they have a job regardless of how many hours it entails. As for the relation between job satisfaction and age, it was found that older employees are more satisfied than younger ones (Böckerman and Ilmakunnas, 2006; Kristensen and Johansson, 2008).

In terms of the relation with work conditions (such as breaks, environment, job security and workload), poor working conditions were found to be negatively affect job satisfaction (Godechot and Gurgand, 2000; Manojlovich, 2005; Zangaro and Soeken, 2007; Cummings et al., 2008; Cortese, et al., 2010). Burnout was found to be negatively related to job satisfaction (Demerouti et al, 2000; Aiken et al., 2002; Bender et al, 2005; Cortese, et al., 2010). Employees were found to be less satisfied when feeling insecure about their jobs (Heaney et al., 1994).

Job satisfaction was found to be related to employees' health and job stress. It was found that higher job satisfaction reduces stress (Jansen, et al., 1996; Faragher, et al 2005). It was also found that low job satisfaction is linked to a range of health issues especially mental/psychological problems (Hoogendoorn et al. 2002; Faragher et al., 2005). Job stress is correlated with job dissatisfaction (Jansen, et al., 1996), a significant correlation was found with job stress and work environment. When job satisfaction was high, job stress and anxiety were found to be low (NewburyBirch and Kamali, 2001; Fairbrother and Warn, 2003; Nandi et al., 2004; Sveinsdottir et al., 2006; Zangaro and Soeken, 2007; Klassen and Chiu 2010).

Job satisfaction was found to be related to employee turnover as low job satisfaction increases the employee's intention to quit his/her job (Jansen, et al., 1996; Bogler 2002; Tzeng, 2002; Parker et al. 2003; Chen, 2006; Scott-Ladd et al., 2006; Clark, et al., 2009; Nadiri and Tanova, 2010). Job satisfaction has an indirect influence on turnover through its direct influence on the formation of intent to leave. Consequently, it has its positive impact on organizational citizenship (Nadiri and Tanova, 2010). Increasing employees' job satisfaction and commitment to the organization will increase not only the extra-role behavior of the employees through organizational citizenship behavior, but will also contribute to the increased competitiveness of hospitality sector organizations and lead to better future performance (Nadiri, and Tanova 2010). This was sustained previously by Schaufeli, et al (2009) as they found that employees who are less satisfied are more likely to be absent.

Job satisfaction is also found to be related to family conflicts as employees who were having family conflicts were found to be less satisfied (Spector et al., 2007; Cortese, et al., 2010). It was found that employees who perceived that the organization was less family-supportive experienced more work-family conflict, less job satisfaction, less organizational commitment, and greater turnover intentions (Allen 2001).

Job satisfaction has been linked to employee-related issues such as empowerment, leadership, job involvement, feedback, and job fairness. Empowerment, psychological in particular, was found to be the major predictor of job satisfaction (Somech and Drach-Zahavy, 2000; Larrabee et al., 2003; Gill, 2008). Job satisfaction is also increased by relational leadership (Pronovost et al. 2003, Manojlovich and Spence Laschinger 2007). Relational leadership increases job satisfaction (Anseel and Lievens 2007; Cummings et al 2008; Cortese, et al., 2010). A lower quality of leadermember exchange was associated with lower levels of in-role and innovative job performance, and with lower job satisfaction (Janssen and Van Yperen 2004).

Job satisfaction and job involvement were found to be significantly correlated as they both exert similar interactive influences on employees' absence measures (Wegge et al., 2007). Employees who are being valued, praised and are given regular feedback (positive and negative) were found to be high in job satisfaction (Gibbs 2001; Anseel and Lievens, 2007; Collins 2008).Workload, lack of autonomy, fairness and work control are all major sources of job dissatisfaction (Janssen 2001; Parker et al. 2003; Cummings et al 2008; Nadiri, and Tanova 2010). Other studies also found that fairness is a predictor of job satisfaction (Colquitt et al., 2001).

Job satisfaction was found to be significantly correlated with various aspects such as coping strategies of the organization (Um and Harrison, 1998), training (Jones, et al., 2009) decision-making (Bogler 2002; Scott-Ladd et al., 2006), experience (Nadiri, and Tanova 2010), financial difficulties (Böckerman and Ilmakunnas, 2006), quality (Bogler 2002) personality traits such as Neuroticism, Extraversion, and Conscientiousness (Judge et al., 2002), and social interaction at work (Ozyurt et al., 2006; Collins 2008; Gittell et al., 2008). Teamwork and supportive climate are important for maintaining job satisfaction (Fairbrother and Warn, 2003).

Based on the above literature, no correlation between the three forms of Organizational commitment and job satisfaction was previously examined in hotels, especially in the Middle East. Therefore, it is important to identify the most significant form of organizational commitment to job satisfaction of hotel employees. 


\section{Methodology}

This paper is part of a project that was conducted in three five-star hotels in Saudi Arabia. The purpose of this study is to explore organizational commitment of employees in Saudi hotels and its relation to their job satisfaction. The study aims to cross-examine the three forms of organizational commitment with job satisfaction. Out of 900 questionnaire forms distributed to hotel staff (all departments), 528 forms were successfully filled out.

A Quantitative approach was used in this study to achieve its aim utilizing two measurement tools. The first tool was LaMastro's (1999) instrument to measure organizational commitment. It is composed of three parts affective, continuance, and normative. Affective Organizational Commitment (AOC) consists of 9 items; Continuance Organizational Commitment (COC) consists of 7 items, and Normative Organizational Commitment (NOC) consists of 6 items. The second tool was Minnesota Satisfaction Questionnaire (MSQ) to measure job satisfaction. This tool is composed of 20 items all together. Both tools were utilized using a 5-point Likert scale in which 5 indicated "strongly agree" and 1 indicated "strongly disagree".

\section{Data collection}

The field study was conducted in three five-star international chained hotels in KSA. The researcher believed that international chained hotels were more convenient for the study due to the adherence of rigorous companies' policies and standard operating procedures, which may reduce the elements of disorder, improvisation, and spontaneity among the way work is done. This is believed to be beneficial to serve the purpose of the research. A total of 900 questionnaire forms were distributed in three major cities in Saudi Arabia: Dammam, Jeddah, and Riyadh. After distributing a total of 900 survey forms to hotel staff (all departments) in three major cities in Saudi Arabia: Dammam, Jeddah, and Riyadh; 528 forms were successfully filled out with a response rate of $58.66 \%$.

\section{Validity and reliability}

In terms of validity, factor analysis test was conducted in the study. Kaiser-Myer-Olkin measure of sampling adequacy resulted in .174. Bartlett's Test of Sphericity resulted.000 significance. In order to test reliability, a Cronbach's Alpha test was used. The Cronbach's Alpha result was .815; Cronbach's Alpha based on standardized items is .915.

\section{Research limitations}

There are some methodological limitations that should be taken into account to maintain the quality of research with regard to this survey. First, it was not possible to cover a large number of hotels for financial reasons. Second, there was no opportunity to check issues relating to employee bias. Possible issues of power bias since employees were worried that their employers may know their answers although it was clearly stated and emphasized that names are not to be written down on survey forms in order to preserve confidentiality. Third, the researcher translated the questionnaire into four other languages in addition to English in order to meet the requirements of the majority of the workforce: Arabic, Hindi, Urdu, and Bengali.

\section{Data analysis}

A computer software package (SPSS 21) was used to analyze data through two tests in the study. First, a descriptive test was conducted to yield descriptive results related to gender, age, and nationality. Second, a Spearman bivariate correlation test was conducted to measure the correlation between each form of Organizational Commitment (Affective, Continuance, and Normative) and Job satisfaction.

\section{Results and Discussion}

\section{Descriptive results}

In terms of gender, $75 \%$ of the employees were males $(n=396)$ and $25 \%$ were females $(n=132)$. Majority of female employees were Saudi (96\%). In terms of age groups, $27.4 \%$ were aged between 18 and 29; 59.2\% were aged between 30 and 39; $13.4 \%$ were aged between 40 and 49. In terms of nationality, 9 different nationalities were found in the whole sample $(n=528)$. The Indians represented $38.6 \%(n=204)$, Saudis $18.2 \%(n=96)$, Bengalis $11.9 \%(n=63)$, Filipinos $10.7 \%(n=57)$, Ethiopians 5.11\% ( $n=27)$, Egyptians 4.5\% $(n=24)$, Moroccans $4.1 \%(n=22)$, Nepalese $2.6 \%$ $(n=14)$, Sudanese $2.2 \%(n=12)$, Tunisians $1.7 \%(n=9)$.

Table 1: Organizational commitment measurement tool (MSQ)

\begin{tabular}{|c|c|c|c|c|c|c|}
\hline \multirow[b]{2}{*}{ \# } & \multirow[b]{2}{*}{ Questions } & \multicolumn{5}{|c|}{ Affective Organizational Commitment } \\
\hline & & $\begin{array}{c}\text { Totally } \\
\text { disagree }\end{array}$ & disagree & average & Agree & $\begin{array}{c}\text { Totally } \\
\text { agree }\end{array}$ \\
\hline AOC1 & I do not feel like part of a family at Sheraton Dammam hotel & & & & & \\
\hline AOC 2 & I feel emotionally attached to Sheraton Dammam hotel & & & & & \\
\hline AOC 3 & Working at Sheraton Dammam hotel has means a lot me. & & & & & \\
\hline AOC 4 & I feel a strong sense of belonging to Sheraton Dammam hotel & & & & & \\
\hline AOC 5 & Sheraton Dammam hotel does not deserve my loyalty & & & & & \\
\hline AOC 6 & I am proud to tell others that I work at Sheraton Dammam hotel & & & & & \\
\hline AOC 7 & I would be happy to work at Sheraton Dammam hotel until I retire & & & & & \\
\hline
\end{tabular}




\begin{tabular}{|c|c|c|c|c|c|c|}
\hline AOC 8 & I see problems faced by the hotel as my own problems & & & & & \\
\hline AOC 9 & I enjoy discussing Sheraton Dammam hotel issues with people outside of it & & & & & \\
\hline \multirow[t]{2}{*}{ ( } & \multirow[t]{2}{*}{ 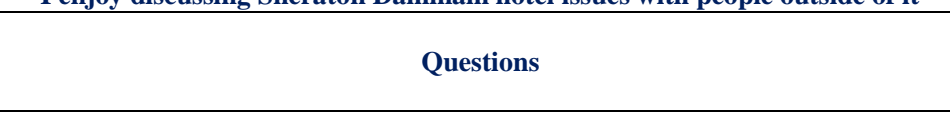 } & \multicolumn{5}{|c|}{ Continuance Organizational Commitment } \\
\hline & & $\begin{array}{c}\text { Totally } \\
\text { disagree }\end{array}$ & disagree & average & Agree & $\begin{array}{c}\text { Totally } \\
\text { agree }\end{array}$ \\
\hline COC1 & $\begin{array}{c}\text { I am not concerned about what may happen if I leave the hotel without having } \\
\text { another offer elsewhere }\end{array}$ & & & & & \\
\hline COC 2 & It would be very hard for me to leave the hotel right now, even if I wanted to & & & & & \\
\hline COC 3 & Too much in my life would be disrupted if I decided to leave the hotel now. & & & & & \\
\hline COC 4 & It wouldn't be too costly for me to leave the hotel now & & & & & \\
\hline $\operatorname{COC} 5$ & Right now, staying at the hotel is a matter of necessity as much as desire & & & & & \\
\hline COC 6 & I cannot leave the hotel due to lack of available alternatives & & & & & \\
\hline COC 7 & I cannot quit as another hotel may not have the overall benefits I have here & & & & & \\
\hline \multirow[b]{2}{*}{ \# } & \multirow[b]{2}{*}{ Questions } & \multicolumn{5}{|c|}{ Normative Organizational Commitment } \\
\hline & & $\begin{array}{c}\text { Totally } \\
\text { disagree }\end{array}$ & disagree & average & Agree & $\begin{array}{c}\text { Totally } \\
\text { agree }\end{array}$ \\
\hline NOC1 & I do not feel any obligation to remain with the hotel & & & & & \\
\hline NOC 2 & Even if it was beneficial, I do not feel it would be right to leave the hotel now & & & & & \\
\hline NOC 3 & I would feel guilty if I leave the hotel now & & & & & \\
\hline NOC 4 & The hotel deserves my loyalty & & & & & \\
\hline NOC 5 & It would be wrong to leave the hotel right now because of my obligation $\mathrm{m}$ & & & & & \\
\hline NOC 6 & I owe a lot to the hotel & & & & & \\
\hline
\end{tabular}

Table 2: Job satisfaction measurement tool (MSQ)

\begin{tabular}{|c|c|c|c|c|c|c|}
\hline \multirow[b]{2}{*}{ VAR. } & \multirow[b]{2}{*}{ Questions } & \multicolumn{5}{|c|}{ Job satisfaction level } \\
\hline & & $\begin{array}{c}\text { Totally } \\
\text { disagree }\end{array}$ & disagree & average & Agree & $\begin{array}{c}\text { Totally } \\
\text { agree }\end{array}$ \\
\hline JS1 & My job keeps me busy all the time. & & & & & \\
\hline JS2 & I get the chance to work alone on the job & & & & & \\
\hline JS3 & I get the chance to do different things from time to time & & & & & \\
\hline JS4 & I get the chance to be somebody in the community & & & & & \\
\hline JS5 & I am satisfied with the way my boss handles his subordinates & & & & & \\
\hline JS6 & I am satisfied with competence of my supervisor in making decisions & & & & & \\
\hline JS7 & My job makes me able to do things that don't go against my conscience & & & & & \\
\hline JS8 & My job provides steady employment & & & & & \\
\hline JS9 & My job gives me the chance to do things for other people & & & & & \\
\hline JS10 & My job gives me the chance to tell people what to do & & & & & \\
\hline JS11 & $\begin{array}{l}\text { My job gives me the chance to do something that makes use of my } \\
\text { abilities }\end{array}$ & & & & & \\
\hline JS12 & I am satisfied with the way company policies are put into practice & & & & & \\
\hline JS 13 & I am satisfied with my salary and the amount of work I do & & & & & \\
\hline JS 14 & I get chances for advancement on my job. & & & & & \\
\hline JS 15 & My job gives me the freedom to use my own judgment & & & & & \\
\hline JS 16 & My job gives me the chance to try my own methods of doing the job & & & & & \\
\hline JS 17 & I am satisfied with the working conditions in the hotel & & & & & \\
\hline JS 18 & I am satisfied with the way my colleagues get along with each other & & & & & \\
\hline JS 19 & I am satisfied with the praise I get for doing a good job & & & & & \\
\hline JS 20 & I am satisfied with the feeling of accomplishment I get from the job & & & & & \\
\hline
\end{tabular}

\section{Affective Organizational Commitment and Job Satisfaction}

In terms of the relation between affective organizational commitment and job satisfaction (as shown in table 3 ), results showed significant correlations (both positive and negative): AOC1: "I do not feel like part of a family at the hotel" was found to be highly significant $(\mathrm{p}<0.005)$ with 16 variables of job satisfaction. AOC2: "I feel emotionally attached to the hotel" was found to be highly significant $(\mathrm{p}<0.005)$ with 19 variables of job satisfaction. AOC3: "Working at the hotel means a lot to me" was found to be highly significant $(\mathrm{p}<0.005)$ with 19 variables of job satisfaction. AOC4: "I feel a strong sense of belonging to the hotel" was found to be highly significant ( $<<0.005)$ with 18 variables of job satisfaction. AOC5: "The hotel does not deserve my loyalty" was found to be highly significant $(\mathrm{p}<0.005)$ with 17 variables of job satisfaction. AOC6: "I am proud to tell others that I work at the hotel" was found to be highly significant ( $\mathrm{p}<0.005)$ with 19 variables of job satisfaction. AOC7: "I would be happy to work at the hotel until I retire" was found to be highly significant $(\mathrm{p}<0.005)$ with all 20 variables of job satisfaction. AOC8: "I see problems faced by the hotel as my own problems" was found to be highly significant ( $\mathrm{p}<0.005$ ) with 17 variables of job satisfaction. AOC9: "I enjoy discussing the hotel issues with people outside of it" was found to be highly significant (p $<0.005)$ with 14 variables of job satisfaction.

These findings indicate that employees who do not feel part of the hotel family are less satisfied. Employees who are emotionally attached to the hotel are more satisfied. Employees who value their work in their hotels are more satisfied. Employees who belong to the hotel are more satisfied. Employees who believe that their loyalty is too expensive to give to their employers are less satisfied. Employees who hold pride in their employers are more satisfied. Employees who are willing to retire in the hotel are more satisfied. Employees who take ownership of the hotel problems are more satisfied. Employees who share work-related problems with their friends and relatives are highly 
satisfied. These findings match with the literature claiming that employees with affective commitment would want to remain within an organization because they are attached to it emotionally (Meyer, Stanley, Herscovitch, \& Topolnytsky, 2002).

Table 3: Correlation between Affective Organizational Commitment (AOC) and Job satisfaction

\begin{tabular}{|c|c|c|c|c|c|c|c|c|c|}
\hline Variables & AOC1 & AOC2 & AOC3 & AOC4 & AOC5 & AOC6 & AOC7 & AOC8 & AOC9 \\
\hline $\begin{array}{l}\text { JS1 (corr.) } \\
\text { Significance }\end{array}$ & $\begin{array}{l}.111 * \\
.010\end{array}$ & $\begin{array}{l}.207 * * \\
.000\end{array}$ & $\begin{array}{l}.275^{* * *} \\
.000\end{array}$ & $\begin{array}{l}.160 * * \\
.000\end{array}$ & $\begin{array}{l}.073 \\
.094 \\
\end{array}$ & $\begin{array}{l}.255^{* *} \\
.000\end{array}$ & $\begin{array}{l}.188 * * \\
.000\end{array}$ & $\begin{array}{l}.199 * * \\
.000\end{array}$ & $\begin{array}{l}.143 * * \\
.001\end{array}$ \\
\hline $\begin{array}{l}\text { JS2 (corr.) } \\
\text { Significance }\end{array}$ & $\begin{array}{l}-.020- \\
.644\end{array}$ & $\begin{array}{l}.102 * \\
.019\end{array}$ & $\begin{array}{l}.398 * * \\
.000\end{array}$ & $\begin{array}{l}.100^{*} \\
.021 \\
\end{array}$ & $\begin{array}{l}-.236-* * \\
.000\end{array}$ & $\begin{array}{l}.006 \\
.884\end{array}$ & $\begin{array}{l}.173 * * \\
.000\end{array}$ & $\begin{array}{l}-.124-* * \\
.004\end{array}$ & $\begin{array}{l}-.085- \\
.051\end{array}$ \\
\hline $\begin{array}{l}\text { JS3 (corr.) } \\
\text { Significance }\end{array}$ & $\begin{array}{l}-.001- \\
.984\end{array}$ & $\begin{array}{l}.195^{* *} * \\
.000\end{array}$ & $\begin{array}{l}.368 * * \\
.000\end{array}$ & $\begin{array}{l}.227 * * \\
.000\end{array}$ & $\begin{array}{l}-.029- \\
.505\end{array}$ & $\begin{array}{l}.257^{* *} * \\
.000\end{array}$ & $\begin{array}{l}.426^{* * *} \\
.000\end{array}$ & $\begin{array}{l}.076 \\
.081\end{array}$ & $\begin{array}{l}.173 * * \\
.000\end{array}$ \\
\hline $\begin{array}{l}\text { JS4 (corr.) } \\
\text { Significance }\end{array}$ & $\begin{array}{l}-.206-* * \\
.000\end{array}$ & $\begin{array}{l}.531 * * \\
.000\end{array}$ & $\begin{array}{l}.420 * * \\
.000\end{array}$ & $\begin{array}{l}.032 \\
.469\end{array}$ & $\begin{array}{l}-.230-* * \\
.000\end{array}$ & $\begin{array}{l}.485^{* *} \\
.000\end{array}$ & $\begin{array}{l}.509 * * \\
.000\end{array}$ & $\begin{array}{l}.509 * * \\
.000\end{array}$ & $\begin{array}{l}.509 * * \\
.007\end{array}$ \\
\hline $\begin{array}{l}\text { JS5 (corr.) } \\
\text { Significance }\end{array}$ & $\begin{array}{l}-.348-* * \\
.000\end{array}$ & $\begin{array}{l}.502 * * \\
.000\end{array}$ & $\begin{array}{l}.253 * * \\
.000\end{array}$ & $\begin{array}{l}.321 * * \\
.000\end{array}$ & $\begin{array}{l}-.160-* * \\
.000\end{array}$ & $\begin{array}{l}.333^{* *} \\
.000\end{array}$ & $\begin{array}{l}.228 * * \\
.000\end{array}$ & $\begin{array}{l}.317 * * \\
.000\end{array}$ & $\begin{array}{l}-.171-* * \\
.000\end{array}$ \\
\hline $\begin{array}{l}\text { JS6 (corr.) } \\
\text { Significance }\end{array}$ & $\begin{array}{l}-.398-* * \\
.000\end{array}$ & $\begin{array}{l}.483 * * \\
.000\end{array}$ & $\begin{array}{l}.426 * * \\
.000\end{array}$ & $\begin{array}{l}.225 * * \\
.000\end{array}$ & $\begin{array}{l}-.278-* * \\
.000\end{array}$ & $\begin{array}{l}.531 * * \\
.000\end{array}$ & $\begin{array}{l}.662 * * \\
.000\end{array}$ & $\begin{array}{l}.355 * * \\
.000\end{array}$ & $\begin{array}{l}-.010- \\
.811\end{array}$ \\
\hline $\begin{array}{l}\text { JS7 (corr.) } \\
\text { Significance }\end{array}$ & $\begin{array}{l}-.124-* * \\
.004\end{array}$ & $\begin{array}{l}.384 * * \\
.000\end{array}$ & $\begin{array}{l}.397 * * \\
.000\end{array}$ & $\begin{array}{l}-.127-* * \\
.003\end{array}$ & $\begin{array}{l}-.137-* * \\
.002\end{array}$ & $\begin{array}{l}.457 * * \\
.000\end{array}$ & $\begin{array}{l}.379 * * \\
.000\end{array}$ & $\begin{array}{l}-.015- \\
.733\end{array}$ & $\begin{array}{l}-.093-* \\
.032\end{array}$ \\
\hline $\begin{array}{l}\text { JS8 (corr.) } \\
\text { Significance }\end{array}$ & $\begin{array}{l}-.196-* * \\
.000\end{array}$ & $\begin{array}{l}.406^{* *} \\
.000\end{array}$ & $\begin{array}{l}.470 * * \\
.000\end{array}$ & $\begin{array}{l}.421 * * \\
.000\end{array}$ & $\begin{array}{l}-.284-* * \\
.000\end{array}$ & $\begin{array}{l}.610^{* *} \\
.000\end{array}$ & $\begin{array}{l}.463 * * \\
.000\end{array}$ & $\begin{array}{l}.155^{* *} \\
.000\end{array}$ & $\begin{array}{l}.157 * * \\
.000\end{array}$ \\
\hline $\begin{array}{l}\text { JS9 (corr.) } \\
\text { Significance }\end{array}$ & $\begin{array}{l}-.404-* * \\
.000\end{array}$ & $\begin{array}{l}.377 * * \\
.000\end{array}$ & $\begin{array}{l}.266^{* * *} \\
.000\end{array}$ & $\begin{array}{l}.193 * * \\
.000\end{array}$ & $\begin{array}{l}-.487-* * \\
.000\end{array}$ & $\begin{array}{l}.269 * * \\
.000\end{array}$ & $\begin{array}{l}.559 * * \\
.000\end{array}$ & $\begin{array}{l}.285^{* *} \\
.000\end{array}$ & $\begin{array}{l}.108^{*} \\
.013\end{array}$ \\
\hline $\begin{array}{l}\text { JS10 (corr.) } \\
\text { Significance }\end{array}$ & $\begin{array}{l}-.129-* * \\
.003\end{array}$ & $\begin{array}{l}.246 * * \\
.000\end{array}$ & $\begin{array}{l}.301 * * \\
.000\end{array}$ & $\begin{array}{l}.396 * * \\
.000\end{array}$ & $\begin{array}{l}-.377-* * \\
.000\end{array}$ & $\begin{array}{l}.155^{* *} \\
.000\end{array}$ & $\begin{array}{l}.231 * * \\
.000\end{array}$ & $\begin{array}{l}.180 * * \\
.000\end{array}$ & $\begin{array}{l}.114 * * \\
.009\end{array}$ \\
\hline $\begin{array}{l}\text { JS11 (corr.) } \\
\text { Significance }\end{array}$ & $\begin{array}{l}-.304-* * \\
.000\end{array}$ & $\begin{array}{l}.278 * * \\
.000\end{array}$ & $\begin{array}{l}.165^{* * *} \\
.000\end{array}$ & $\begin{array}{l}.271 * * \\
.000\end{array}$ & $\begin{array}{l}-.501-* * \\
.000\end{array}$ & $\begin{array}{l}.210^{* *} \\
.000\end{array}$ & $\begin{array}{l}.270 * * \\
.000\end{array}$ & $\begin{array}{l}.443^{* *} \\
.000\end{array}$ & $\begin{array}{l}-.057- \\
.193\end{array}$ \\
\hline $\begin{array}{l}\text { JS12 (corr.) } \\
\text { Significance }\end{array}$ & $\begin{array}{l}-.386-* * \\
.000\end{array}$ & $\begin{array}{l}.321 * * \\
.000\end{array}$ & $\begin{array}{l}.330 * * \\
.000\end{array}$ & $\begin{array}{l}.475 * * \\
.000\end{array}$ & $\begin{array}{l}-.228-* * \\
.000\end{array}$ & $\begin{array}{l}.224 * * \\
.000\end{array}$ & $\begin{array}{l}.400 * * \\
.000\end{array}$ & $\begin{array}{l}.261 * * \\
.000\end{array}$ & $\begin{array}{l}-.011- \\
.808\end{array}$ \\
\hline $\begin{array}{l}\text { JS13 (corr.) } \\
\text { Significance }\end{array}$ & $\begin{array}{l}.072 \\
.009\end{array}$ & $\begin{array}{l}.268 * * \\
.000\end{array}$ & $\begin{array}{l}.095^{*} \\
.029\end{array}$ & $\begin{array}{l}.129 * * \\
.003\end{array}$ & $\begin{array}{l}.088 * \\
.042\end{array}$ & $\begin{array}{l}.264 * * \\
.000\end{array}$ & $\begin{array}{l}.230 * * \\
.000\end{array}$ & $\begin{array}{l}.320 * * \\
.000\end{array}$ & $\begin{array}{l}.305^{* *} \\
.808\end{array}$ \\
\hline $\begin{array}{l}\text { JS14 (corr.) } \\
\text { Significance }\end{array}$ & $\begin{array}{l}-.466-* * \\
.000\end{array}$ & $\begin{array}{l}-.466-* * \\
.000\end{array}$ & $\begin{array}{l}.371 * * \\
.000\end{array}$ & $\begin{array}{l}.359 * * \\
.000\end{array}$ & $\begin{array}{l}-.405-* * \\
.000\end{array}$ & $\begin{array}{l}.423^{* *} \\
.000\end{array}$ & $\begin{array}{l}.511 * * \\
.000\end{array}$ & $\begin{array}{l}.446^{* * *} \\
.000\end{array}$ & $\begin{array}{l}.155^{* * *} \\
.000\end{array}$ \\
\hline $\begin{array}{l}\text { JS15 (corr.) } \\
\text { Significance }\end{array}$ & $\begin{array}{l}-.316-* * \\
.000\end{array}$ & $\begin{array}{l}.223 * * \\
.000\end{array}$ & $\begin{array}{l}.287^{* * *} \\
.000\end{array}$ & $\begin{array}{l}.311 * * \\
.000\end{array}$ & $\begin{array}{l}-.171-* * \\
.000\end{array}$ & $\begin{array}{l}.149 * * \\
.001\end{array}$ & $\begin{array}{l}.495 * * \\
.000\end{array}$ & $\begin{array}{l}.479 * * \\
.000\end{array}$ & $\begin{array}{l}.113^{* *} \\
.010\end{array}$ \\
\hline $\begin{array}{l}\text { JS16 (corr.) } \\
\text { Significance }\end{array}$ & $\begin{array}{l}-.283-* * \\
.000\end{array}$ & $\begin{array}{l}.347 * * \\
.000\end{array}$ & $\begin{array}{l}.412^{* * *} \\
.000\end{array}$ & $\begin{array}{l}.189 * * \\
.000\end{array}$ & $\begin{array}{l}-.135-* * \\
.002\end{array}$ & $\begin{array}{l}.348 * * \\
.000\end{array}$ & $\begin{array}{l}.440 * * \\
.000\end{array}$ & $\begin{array}{l}.372 * * \\
.000\end{array}$ & $\begin{array}{l}.210^{* *} \\
.000\end{array}$ \\
\hline $\begin{array}{l}\text { JS17 (corr.) } \\
\text { Significance }\end{array}$ & $\begin{array}{l}-.408-* * \\
.000\end{array}$ & $\begin{array}{l}.345^{* *} \\
.000\end{array}$ & $\begin{array}{l}.447 * * \\
.000\end{array}$ & $\begin{array}{l}.489 * * \\
.000\end{array}$ & $\begin{array}{l}-.392-* * \\
.000\end{array}$ & $\begin{array}{l}.414 * * \\
.000\end{array}$ & $\begin{array}{l}.409 * * \\
.000\end{array}$ & $\begin{array}{l}.062 \\
.154\end{array}$ & $\begin{array}{l}-.146-* * \\
.001\end{array}$ \\
\hline $\begin{array}{l}\text { JS18 (corr.) } \\
\text { Significance }\end{array}$ & $\begin{array}{l}-.304-* * \\
.000\end{array}$ & $\begin{array}{l}.500 * * \\
.000\end{array}$ & $\begin{array}{l}.587 * * \\
.000\end{array}$ & $\begin{array}{l}.386^{* * *} \\
.000\end{array}$ & $\begin{array}{l}-.255-* * \\
.000\end{array}$ & $\begin{array}{l}.237 * * \\
.000\end{array}$ & $\begin{array}{l}.228 * * \\
.000\end{array}$ & $\begin{array}{l}-.098-* \\
.000\end{array}$ & $\begin{array}{l}-.035- \\
.024\end{array}$ \\
\hline $\begin{array}{l}\text { JS19 (corr.) } \\
\text { Significance }\end{array}$ & $\begin{array}{l}-.375-* * \\
.000\end{array}$ & $\begin{array}{l}.281 * * \\
.000\end{array}$ & $\begin{array}{l}.185^{* * *} \\
.000\end{array}$ & $\begin{array}{l}.388 * * \\
.000\end{array}$ & $\begin{array}{l}-.146-* * \\
.001\end{array}$ & $\begin{array}{l}.226^{* * *} \\
.000\end{array}$ & $\begin{array}{l}.150 * * \\
.001\end{array}$ & $\begin{array}{l}.113 * * \\
.000\end{array}$ & $\begin{array}{l}.201 * * \\
.009\end{array}$ \\
\hline $\begin{array}{l}\text { JS20 (corr.) } \\
\text { Significance }\end{array}$ & $\begin{array}{l}-.543-* * \\
.000\end{array}$ & $\begin{array}{l}.568 * * \\
.000\end{array}$ & $\begin{array}{l}.576 * * \\
.000\end{array}$ & $\begin{array}{l}.155^{* *} \\
.000\end{array}$ & $\begin{array}{l}-.345-* * \\
.000\end{array}$ & $\begin{array}{l}.343 * * \\
.000\end{array}$ & $\begin{array}{l}.656 * * \\
.000\end{array}$ & $\begin{array}{l}.134 * * \\
.000\end{array}$ & $\begin{array}{l}-.080- \\
.002\end{array}$ \\
\hline
\end{tabular}

\section{Continuance Organizational Commitment and Job Satisfaction}

In terms of the relation between continuance organizational commitment and job satisfaction, results showed significant correlations (both positive and negative): COC1: "I am not concerned about what may happen if I leave the hotel without having another offer elsewhere" was found to be highly significant $(\mathrm{p}<0.005)$ with 11 variables of job satisfaction. COC2: "It would be very hard for me to leave the hotel right now, even if I wanted to" was found to be highly significant ( $\mathrm{p}<0.005)$ with 16 variables of job satisfaction. COC3: "Too much in my life would be disrupted if I decided to leave the hotel now" was found to be highly significant ( $p<0.005)$ with 8 variables of job satisfaction. COC4: "It wouldn't be too costly for me to leave the hotel now" was found to be highly significant (p < 0.005) with 7 variables of job satisfaction. COC5: "Right now, staying at the hotel is a matter of necessity as much as a desire" was found to be highly significant ( $\mathrm{p}<0.005)$ with 14 variables of job satisfaction. COC6: "I cannot leave the hotel due to lack of available alternatives" was found to be highly significant $(\mathrm{p}<0.005)$ with 13 variables of job satisfaction. COC7: "I cannot leave the hotel as another hotel may not have the overall benefits I have here" was found to be highly significant $(\mathrm{p}<0.005)$ with 10 variables of job satisfaction. 
Table 4: Correlation between Continuance Organizational Commitment (COC) and Job satisfaction

\begin{tabular}{|c|c|c|c|c|c|c|c|}
\hline Variables & COC1 & COC2 & COC3 & COC4 & COC5 & COC6 & COC7 \\
\hline $\begin{array}{l}\text { JS1 (corr.) } \\
\text { Significance }\end{array}$ & $\begin{array}{l}.276 * * \\
.000\end{array}$ & $\begin{array}{l}.022 \\
.614\end{array}$ & $\begin{array}{l}.080 \\
.066\end{array}$ & $\begin{array}{l}.035 \\
.427\end{array}$ & $\begin{array}{l}.050- \\
.247\end{array}$ & $\begin{array}{l}.337 * * \\
.000\end{array}$ & $\begin{array}{l}.449 * * \\
.000\end{array}$ \\
\hline $\begin{array}{l}\text { JS2 (corr.) } \\
\text { Significance }\end{array}$ & $\begin{array}{l}.120^{* *} \\
.006\end{array}$ & $\begin{array}{l}.130 * * \\
.003\end{array}$ & $\begin{array}{l}.304 * * \\
.000\end{array}$ & $\begin{array}{l}.039 \\
.373\end{array}$ & $\begin{array}{l}-.015- \\
.729 \\
\end{array}$ & $\begin{array}{l}-.297-* * \\
.000\end{array}$ & $\begin{array}{l}.048 \\
.268 \\
\end{array}$ \\
\hline $\begin{array}{l}\text { JS3 (corr.) } \\
\text { Significance } \\
\end{array}$ & $\begin{array}{l}.127 * * \\
.003 \\
\end{array}$ & $\begin{array}{l}.055 \\
.203 \\
\end{array}$ & $\begin{array}{l}-.082- \\
.060 \\
\end{array}$ & $\begin{array}{l}.160 * * \\
.000\end{array}$ & $\begin{array}{l}.123 * * \\
.005 \\
\end{array}$ & $\begin{array}{l}.049 \\
.258 \\
\end{array}$ & $\begin{array}{l}.387 * * \\
.000 \\
\end{array}$ \\
\hline $\begin{array}{l}\text { JS4 (corr.) } \\
\text { Significance }\end{array}$ & $\begin{array}{l}-.163-* * \\
.000\end{array}$ & $\begin{array}{l}.446 * * \\
.000\end{array}$ & $\begin{array}{l}.300 * * \\
.000\end{array}$ & $\begin{array}{l}.120 * * \\
.006\end{array}$ & $\begin{array}{l}.261 * * \\
.000\end{array}$ & $\begin{array}{l}-.086-* \\
.048\end{array}$ & $\begin{array}{l}.123^{* *} \\
.005\end{array}$ \\
\hline $\begin{array}{l}\text { JS5 (corr.) } \\
\text { Significance } \\
\end{array}$ & $\begin{array}{l}-.202-* * \\
.000 \\
\end{array}$ & $\begin{array}{l}.335 * * \\
.000\end{array}$ & $\begin{array}{l}.027 \\
.534 \\
\end{array}$ & $\begin{array}{l}.000 \\
1.000 \\
\end{array}$ & $\begin{array}{l}.195 * * \\
.000\end{array}$ & $\begin{array}{l}.334 * * \\
.000 \\
\end{array}$ & $\begin{array}{l}.225^{* *} \\
.000 \\
\end{array}$ \\
\hline $\begin{array}{l}\text { JS6 (corr.) } \\
\text { Significance }\end{array}$ & $\begin{array}{l}-.120-* * \\
.006\end{array}$ & $\begin{array}{l}.367 * * \\
.000\end{array}$ & $\begin{array}{l}-.005- \\
.908 \\
\end{array}$ & $\begin{array}{l}.016- \\
.707 \\
\end{array}$ & $\begin{array}{l}.015 \\
.734 \\
\end{array}$ & $\begin{array}{l}.413 * * \\
.000\end{array}$ & $\begin{array}{l}.426^{* *} \\
.000 \\
\end{array}$ \\
\hline $\begin{array}{l}\text { JS7 (corr.) } \\
\text { Significance } \\
\end{array}$ & $\begin{array}{l}.369-* * \\
.000 \\
\end{array}$ & $\begin{array}{l}.195^{* * *} \\
.000 \\
\end{array}$ & $\begin{array}{l}.191 * * \\
.000 \\
\end{array}$ & $\begin{array}{l}.146-* * \\
.001 \\
\end{array}$ & $\begin{array}{l}.116^{* * *} \\
.007 \\
\end{array}$ & $\begin{array}{l}-.077- \\
.077 \\
\end{array}$ & $\begin{array}{l}.145^{* * *} \\
.001 \\
\end{array}$ \\
\hline $\begin{array}{l}\text { JS8 (corr.) } \\
\text { Significance } \\
\end{array}$ & $\begin{array}{l}.057- \\
.192 \\
\end{array}$ & $\begin{array}{l}.411 * * \\
.000 \\
\end{array}$ & $\begin{array}{l}.304 * * \\
.000 \\
\end{array}$ & $\begin{array}{l}.289 * * \\
.000 \\
\end{array}$ & $\begin{array}{l}.418^{* * *} \\
.000 \\
\end{array}$ & $\begin{array}{l}.271 * * \\
.000 \\
\end{array}$ & $\begin{array}{l}.018 \\
.675 \\
\end{array}$ \\
\hline $\begin{array}{l}\text { JS9 (corr.) } \\
\text { Significance } \\
\end{array}$ & $\begin{array}{l}-.165-* * \\
.000 \\
\end{array}$ & $\begin{array}{l}.064 \\
.142 \\
\end{array}$ & $\begin{array}{l}.142 * * \\
.001 \\
\end{array}$ & $\begin{array}{l}.000 \\
1.000 \\
\end{array}$ & $\begin{array}{l}.088^{*} \\
.043 \\
\end{array}$ & $\begin{array}{l}-.146-* * \\
.001 \\
\end{array}$ & $\begin{array}{l}.300^{* * *} \\
.000 \\
\end{array}$ \\
\hline $\begin{array}{l}\text { JS10 (corr.) } \\
\text { Significance } \\
\end{array}$ & $\begin{array}{l}.036- \\
.413 \\
\end{array}$ & $\begin{array}{l}.108^{*} \\
.013 \\
\end{array}$ & $\begin{array}{l}.207 * * \\
.000 \\
\end{array}$ & $\begin{array}{l}-.009- \\
.834 \\
\end{array}$ & $\begin{array}{l}-.116-* * \\
.008\end{array}$ & $\begin{array}{l}.202 * * \\
.000 \\
\end{array}$ & $\begin{array}{l}.351^{* * *} \\
.000 \\
\end{array}$ \\
\hline $\begin{array}{l}\text { JS11 (corr.) } \\
\text { Significance } \\
\end{array}$ & $\begin{array}{l}.397-* * \\
.000 \\
\end{array}$ & $\begin{array}{l}.154 * * \\
.000 \\
\end{array}$ & $\begin{array}{l}.079 \\
.068 \\
\end{array}$ & $\begin{array}{l}-.007- \\
.865 \\
\end{array}$ & $\begin{array}{l}-.094-* \\
.030 \\
\end{array}$ & $-.018-.681$ & $\begin{array}{l}.196^{* * *} \\
.000 \\
\end{array}$ \\
\hline $\begin{array}{l}\text { JS12 (corr.) } \\
\text { Significance } \\
\end{array}$ & $\begin{array}{l}.167 * * \\
.000 \\
\end{array}$ & $\begin{array}{l}.122^{* * *} \\
.005\end{array}$ & $\begin{array}{l}.029- \\
.513 \\
\end{array}$ & $\begin{array}{l}.068 \\
.117 \\
\end{array}$ & $\begin{array}{l}.190 * * \\
.000 \\
\end{array}$ & $\begin{array}{l}.261^{* * *} \\
.000 \\
\end{array}$ & $\begin{array}{l}.332^{* * *} \\
.000 \\
\end{array}$ \\
\hline $\begin{array}{l}\text { JS13 (corr.) } \\
\text { Significance } \\
\end{array}$ & $\begin{array}{l}.196 * * \\
.000 \\
\end{array}$ & $\begin{array}{l}.310 * * \\
.000\end{array}$ & $\begin{array}{l}. .013- \\
.771 \\
\end{array}$ & $\begin{array}{l}.363 * * \\
.000 \\
\end{array}$ & $\begin{array}{l}.280^{* *} \\
.000 \\
\end{array}$ & $\begin{array}{l}.479^{* *} \\
.000 \\
\end{array}$ & $\begin{array}{l}.227^{* * *} \\
.000 \\
\end{array}$ \\
\hline $\begin{array}{l}\text { JS14 (corr.) } \\
\text { Significance } \\
\end{array}$ & $\begin{array}{l}-.105-* \\
.016 \\
\end{array}$ & $\begin{array}{l}.257 * * \\
.000\end{array}$ & $\begin{array}{l}.064 \\
.140 \\
\end{array}$ & $\begin{array}{l}.061 \\
.159 \\
\end{array}$ & $\begin{array}{l}.041 \\
.345 \\
\end{array}$ & $\begin{array}{l}.260 * * \\
.000 \\
\end{array}$ & $\begin{array}{l}.360 * * \\
.000 \\
\end{array}$ \\
\hline $\begin{array}{l}\text { JS15 (corr.) } \\
\text { Significance } \\
\end{array}$ & $\begin{array}{l}.112 * \\
.010 \\
\end{array}$ & $\begin{array}{l}.283 * * \\
.000 \\
\end{array}$ & $\begin{array}{l}.007 \\
.876 \\
\end{array}$ & $\begin{array}{l}.086-* \\
.048 \\
\end{array}$ & $\begin{array}{l}.112 * * \\
.010 \\
\end{array}$ & $\begin{array}{l}.496^{* * *} \\
.000 \\
\end{array}$ & $\begin{array}{l}.512^{* * *} \\
.000 \\
\end{array}$ \\
\hline $\begin{array}{l}\text { JS16 (corr.) } \\
\text { Significance } \\
\end{array}$ & $\begin{array}{l}. .128-* * \\
.003 \\
\end{array}$ & $\begin{array}{l}.250 * * \\
.000 \\
\end{array}$ & $\begin{array}{l}.077- \\
.077 \\
\end{array}$ & $\begin{array}{l}.088^{*} \\
.044 \\
\end{array}$ & $\begin{array}{l}.177 * * \\
.000 \\
\end{array}$ & $\begin{array}{l}.044 \\
.313 \\
\end{array}$ & $\begin{array}{l}.187^{* * *} \\
.000 \\
\end{array}$ \\
\hline $\begin{array}{l}\text { JS17 (corr.) } \\
\text { Significance } \\
\end{array}$ & $\begin{array}{l}-.201-* * \\
.000\end{array}$ & $\begin{array}{l}.272 * * \\
.000\end{array}$ & $\begin{array}{l}-.009- \\
.831 \\
\end{array}$ & $\begin{array}{l}.124 * * \\
.004\end{array}$ & $\begin{array}{l}.153 * * \\
.000\end{array}$ & $\begin{array}{l}.086^{*} \\
.048\end{array}$ & $\begin{array}{l}.287 * * \\
.000\end{array}$ \\
\hline $\begin{array}{l}\text { JS18 (corr.) } \\
\text { Significance } \\
\end{array}$ & $\begin{array}{l}.035- \\
.418 \\
\end{array}$ & $\begin{array}{l}.328 * * \\
.000\end{array}$ & $\begin{array}{l}.375 * * \\
.000 \\
\end{array}$ & $\begin{array}{l}.092 * \\
.035 \\
\end{array}$ & $\begin{array}{l}.169 * * \\
.000\end{array}$ & $\begin{array}{l}.315^{* *} \\
.000 \\
\end{array}$ & $\begin{array}{l}.305^{* *} \\
.000 \\
\end{array}$ \\
\hline $\begin{array}{l}\text { JS19 (corr.) } \\
\text { Significance } \\
\end{array}$ & $\begin{array}{l}.201 * * \\
.000 \\
\end{array}$ & $\begin{array}{l}.224 * * \\
.000 \\
\end{array}$ & $\begin{array}{l}.028- \\
.518 \\
\end{array}$ & $\begin{array}{l}.109^{*} \\
.012 \\
\end{array}$ & $\begin{array}{l}.150 * * \\
.001 \\
\end{array}$ & $\begin{array}{l}.247 * * \\
.000 \\
\end{array}$ & $\begin{array}{l}.031 \\
.477 \\
\end{array}$ \\
\hline $\begin{array}{l}\text { JS20 (corr.) } \\
\text { Significance }\end{array}$ & $\begin{array}{l}.080- \\
.067 \\
\end{array}$ & $\begin{array}{l}.347 * * \\
.000\end{array}$ & $\begin{array}{l}.208^{* * *} \\
.000\end{array}$ & $\begin{array}{l}.185^{* * *} \\
.000\end{array}$ & $\begin{array}{l}.123 * * \\
.005\end{array}$ & $\begin{array}{l}.107-* \\
.014 \\
\end{array}$ & $\begin{array}{l}.130^{* * *} \\
.003 \\
\end{array}$ \\
\hline
\end{tabular}

These findings indicate that employees who are willing to leave the hotel even without another work offer are less satisfied. Yet they still are obligated to work due to lack of other alternatives. Employees who see the difficulty of leaving the hotel are more satisfied. Employees who believe they will be negatively affected if they leave the hotel are more satisfied. Employees who believe they can afford to leave the hotel are more satisfied. Employees who see the need and desire to stay working for the hotel are more satisfied. Employees who cannot see, feel, or value the benefits provided by their employers are less satisfied. These findings also agreed with the literature as Continuance Organizational Commitment involves the employee's bond to the employer based on what it would cost him/her to leave. Continuance commitment is said to occur out of need, whether due to lack of alternatives or costs associated with leaving, such as lost income, seniority or retirement benefits (Meyer \& Allen, 1991).

\section{Normative Organizational Commitment and Job Satisfaction}

In terms of the relation between continuance organizational commitment and job satisfaction, results showed significant correlations (both positive and negative): NOC1: "I do not feel any obligation to remain with the hotel" was found to be highly significant $(\mathrm{p}<0.005)$ with 14 variables of job satisfaction. NOC2: "Even if it was beneficial, I do not feel it would be right to leave the hotel now" was found to be highly significant ( $\mathrm{p}<0.005)$ with 6 variables of job satisfaction. NOC3: "I would feel guilty if I leave the hotel now" was found to be highly significant $(\mathrm{p}<0.005)$ with 17 variables of job satisfaction. NOC4: "The hotel deserves my loyalty" was found to be highly significant $(\mathrm{p}<0.005)$ with 17 variables of job satisfaction. NOC5: "It would be wrong to leave the hotel right now because of my obligation" was found to be highly significant $(\mathrm{p}<0.005)$ with 18 variables of job satisfaction. NOC6: "I owe a lot to the hotel" was found to be highly significant $(\mathrm{p}<0.005)$ with 19 variables of job satisfaction. 
Table 5: Correlation between Normative Organizational Commitment (NOC) and Job satisfaction

\begin{tabular}{|c|c|c|c|c|c|c|}
\hline Variables & NOC1 & NOC2 & NOC3 & NOC4 & NOC5 & NOC6 \\
\hline $\begin{array}{l}\text { JS1 (corr.) } \\
\text { Significance }\end{array}$ & $\begin{array}{l}-.149-* * \\
.001\end{array}$ & $\begin{array}{l}-.001- \\
.973\end{array}$ & $\begin{array}{l}.040 \\
.361\end{array}$ & $\begin{array}{l}.198^{* * *} \\
.000\end{array}$ & $\begin{array}{l}.140 * * \\
.001\end{array}$ & $\begin{array}{l}.264 * * \\
.000\end{array}$ \\
\hline $\begin{array}{l}\text { JS2 (corr.) } \\
\text { Significance }\end{array}$ & $\begin{array}{l}-.014- \\
.749\end{array}$ & $\begin{array}{l}.047 \\
.278\end{array}$ & $\begin{array}{l}.056 \\
.200\end{array}$ & $\begin{array}{l}-.084- \\
.054\end{array}$ & $\begin{array}{l}-.089-* \\
.042\end{array}$ & $\begin{array}{l}-.084- \\
.054\end{array}$ \\
\hline $\begin{array}{l}\text { JS3 (corr.) } \\
\text { Significance }\end{array}$ & $\begin{array}{l}-.137-* * \\
.002\end{array}$ & $\begin{array}{l}.124 * * \\
.004\end{array}$ & $\begin{array}{l}.255^{* *} \\
.000\end{array}$ & $\begin{array}{l}.449 * * \\
.000\end{array}$ & $\begin{array}{l}.254 * * \\
.000\end{array}$ & $\begin{array}{l}.345^{* *} \\
.000\end{array}$ \\
\hline $\begin{array}{l}\text { JS4 (corr.) } \\
\text { Significance }\end{array}$ & $\begin{array}{l}.213 * * \\
.000\end{array}$ & $\begin{array}{l}.079 \\
.070\end{array}$ & $\begin{array}{l}.303 * * \\
.000\end{array}$ & $\begin{array}{l}.295 * * \\
.000\end{array}$ & $\begin{array}{l}.425 * * \\
.000\end{array}$ & $\begin{array}{l}.402 * * \\
.000\end{array}$ \\
\hline $\begin{array}{l}\text { JS5 (corr.) } \\
\text { Significance }\end{array}$ & $\begin{array}{l}.186^{* * *} \\
.000\end{array}$ & $\begin{array}{l}.321^{* * *} \\
.000\end{array}$ & $\begin{array}{l}.524 * * \\
.000\end{array}$ & $\begin{array}{l}.618^{* * *} \\
.000\end{array}$ & $\begin{array}{l}.548^{* * *} \\
.000\end{array}$ & $\begin{array}{l}.544 * * \\
.000\end{array}$ \\
\hline $\begin{array}{l}\text { JS6 (corr.) } \\
\text { Significance }\end{array}$ & $\begin{array}{l}.104 * \\
.017\end{array}$ & $\begin{array}{l}.099 * \\
.023\end{array}$ & $\begin{array}{l}.531 * * \\
.000\end{array}$ & $\begin{array}{l}.406^{* * *} \\
.000\end{array}$ & $\begin{array}{l}.520 * * \\
.000\end{array}$ & $\begin{array}{l}.522 * * \\
.000\end{array}$ \\
\hline $\begin{array}{l}\text { JS7 (corr.) } \\
\text { Significance }\end{array}$ & $\begin{array}{l}.083 \\
.057\end{array}$ & $\begin{array}{l}-.107-* \\
.014\end{array}$ & $\begin{array}{l}.054 \\
.212\end{array}$ & $\begin{array}{l}.092 * \\
.035\end{array}$ & $\begin{array}{l}.065 \\
.135\end{array}$ & $\begin{array}{l}.121^{* * *} \\
.005\end{array}$ \\
\hline $\begin{array}{l}\text { JS8 (corr.) } \\
\text { Significance }\end{array}$ & $\begin{array}{l}.303 * * \\
.000\end{array}$ & $\begin{array}{l}.140 * * \\
.001\end{array}$ & $\begin{array}{l}.501 * * \\
.000\end{array}$ & $\begin{array}{l}.348 * * \\
.000\end{array}$ & $\begin{array}{l}.307 * * \\
.000\end{array}$ & $\begin{array}{l}.405 * * \\
.000\end{array}$ \\
\hline $\begin{array}{l}\text { JS9 (corr.) } \\
\text { Significance }\end{array}$ & $\begin{array}{l}.282^{* * *} \\
.000\end{array}$ & $\begin{array}{l}.104-* \\
.017\end{array}$ & $\begin{array}{l}.383^{* * *} \\
.000\end{array}$ & $\begin{array}{l}.234 * * \\
.000\end{array}$ & $\begin{array}{l}.219^{* * *} \\
.000\end{array}$ & $\begin{array}{l}.260 * * \\
.000\end{array}$ \\
\hline $\begin{array}{l}\text { JS10 (corr.) } \\
\text { Significance }\end{array}$ & $\begin{array}{l}.046 \\
.296\end{array}$ & $\begin{array}{l}-.038- \\
.386\end{array}$ & $\begin{array}{l}.275^{* *} \\
.000\end{array}$ & $\begin{array}{l}.204 * * \\
.000\end{array}$ & $\begin{array}{l}.251 * * \\
.000\end{array}$ & $\begin{array}{l}.304 * * \\
.000\end{array}$ \\
\hline $\begin{array}{l}\text { JS11 (corr.) } \\
\text { Significance }\end{array}$ & $\begin{array}{l}.556^{* *} \\
.000\end{array}$ & $\begin{array}{l}.050 \\
.248\end{array}$ & $\begin{array}{l}.322 * * \\
.000\end{array}$ & $\begin{array}{l}.328^{* *} \\
.000\end{array}$ & $\begin{array}{l}.289 * * \\
.000\end{array}$ & $\begin{array}{l}.382 * * \\
.000\end{array}$ \\
\hline $\begin{array}{l}\text { JS12 (corr.) } \\
\text { Significance }\end{array}$ & $\begin{array}{l}.376^{* * *} \\
.000\end{array}$ & $\begin{array}{l}.071 \\
.105\end{array}$ & $\begin{array}{l}.643 * * \\
.000\end{array}$ & $\begin{array}{l}.595^{* * *} \\
.000\end{array}$ & $\begin{array}{l}.357 * * \\
.000\end{array}$ & $\begin{array}{l}.432 * * \\
.000\end{array}$ \\
\hline $\begin{array}{l}\text { JS13 (corr.) } \\
\text { Significance }\end{array}$ & $\begin{array}{l}.083 \\
.056\end{array}$ & $\begin{array}{l}.028 \\
.525\end{array}$ & $\begin{array}{l}.384 * * \\
.000\end{array}$ & $\begin{array}{l}.074 \\
.089\end{array}$ & $\begin{array}{l}.212 * * \\
.000\end{array}$ & $\begin{array}{l}.430 * * \\
.000\end{array}$ \\
\hline $\begin{array}{l}\text { JS14 (corr.) } \\
\text { Significance }\end{array}$ & $\begin{array}{l}.237 * * \\
.000\end{array}$ & $\begin{array}{l}-.077- \\
.077\end{array}$ & $\begin{array}{l}.566^{* * *} \\
.000\end{array}$ & $\begin{array}{l}.516^{* * *} \\
.000\end{array}$ & $\begin{array}{l}.386 * * \\
.000\end{array}$ & $\begin{array}{l}.491 * * \\
.000\end{array}$ \\
\hline $\begin{array}{l}\text { JS15 (corr.) } \\
\text { Significance }\end{array}$ & $\begin{array}{l}.040 \\
.355\end{array}$ & $\begin{array}{l}.247 * * \\
.000\end{array}$ & $\begin{array}{l}.584 * * \\
.000\end{array}$ & $\begin{array}{l}.465^{* *} \\
.000\end{array}$ & $\begin{array}{l}.459 * * \\
.000\end{array}$ & $\begin{array}{l}.587 * * \\
.000\end{array}$ \\
\hline $\begin{array}{l}\text { JS16 (corr.) } \\
\text { Significance }\end{array}$ & $\begin{array}{l}.196^{* * *} \\
.000\end{array}$ & $\begin{array}{l}.102 * \\
.020\end{array}$ & $\begin{array}{l}.612^{* * *} \\
.000\end{array}$ & $\begin{array}{l}.508^{* * *} \\
.000\end{array}$ & $\begin{array}{l}.338^{* * *} \\
.000\end{array}$ & $\begin{array}{l}.571 * * \\
.000\end{array}$ \\
\hline $\begin{array}{l}\text { JS17 (corr.) } \\
\text { Significance }\end{array}$ & $\begin{array}{l}.355^{* *} \\
.000\end{array}$ & $\begin{array}{l}.076 \\
.079\end{array}$ & $\begin{array}{l}.540 * * \\
.000\end{array}$ & $\begin{array}{l}.552 * * \\
.000\end{array}$ & $\begin{array}{l}.118 * * \\
.000\end{array}$ & $\begin{array}{l}.382 * * \\
.000\end{array}$ \\
\hline $\begin{array}{l}\text { JS18 (corr.) } \\
\text { Significance }\end{array}$ & $\begin{array}{l}.158^{* * *} \\
.000\end{array}$ & $\begin{array}{l}.142 * * \\
.001\end{array}$ & $\begin{array}{l}.318^{* * *} \\
.000\end{array}$ & $\begin{array}{l}.567 * * \\
.000\end{array}$ & $\begin{array}{l}.377 * * \\
.000\end{array}$ & $\begin{array}{l}.429 * * \\
.000\end{array}$ \\
\hline $\begin{array}{l}\text { JS19 (corr.) } \\
\text { Significance }\end{array}$ & $\begin{array}{l}.280^{* *} \\
.000\end{array}$ & $\begin{array}{l}.231 * * \\
.000\end{array}$ & $\begin{array}{l}.452 * * \\
.000\end{array}$ & $\begin{array}{l}.552 * * \\
.000\end{array}$ & $\begin{array}{l}.468 * * \\
.000\end{array}$ & $\begin{array}{l}.508 * * \\
.000\end{array}$ \\
\hline $\begin{array}{l}\text { JS20 (corr.) } \\
\text { Significance }\end{array}$ & $\begin{array}{l}.236^{* *} \\
.000\end{array}$ & $\begin{array}{l}.074 \\
.089\end{array}$ & $\begin{array}{l}.601 * * \\
.000\end{array}$ & $\begin{array}{l}.460^{* *} \\
.000\end{array}$ & $\begin{array}{l}.459 * * \\
.000\end{array}$ & $\begin{array}{l}.435 * * \\
.000\end{array}$ \\
\hline
\end{tabular}

Employees who do not feel obligated to stay with their employer are more satisfied. Employees who do not believe in leaving the hotel even if it was righteous are less satisfied. Employees who would feel guilty leaving the hotel are more satisfied. Employees who believe that their employer is worth their loyalty are more satisfied. Employees who believe that their obligation toward their employers disables them from leaving are more satisfied. Employees who believe that they owe a lot to the hotel are more satisfied. These findings agree with the literature as Normative Organizational Commitment involves a feeling of moral obligation to continue working for a particular organization. Normatively committed employees feel that they ought to remain with the organization (Meyer \& Allen, 1991). Despite the fact that, in the literature, Continuance Organizational Commitment was found to be the most significant form of related to employee turnover (Huselid and Day, 1991; Paré and Tremblay, 2007), results show that Affective Organizational Commitment is the most significant form of Organizational Commitment that relates to Job satisfaction. This finding was only supported by Meyer et al. (2002) as they found that affective commitment was correlated negatively with absenteeism (Meyer, et al., 2002). Continuance Organizational Commitment, on the other hand, was found to be least significant to job satisfaction.

\section{Recommendations and Conclusion}

Organizational commitment is the psychological state that binds an employee to an organization. There are three main forms of Organizational commitment: affective, continuance, and normative. This study aimed to explore organizational commitment of employees in Saudi hotels and its relation to their job satisfaction. The study aimed to cross-examine the three forms of organizational commitment with job satisfaction. The study used LaMastro's (1999) instrument to measure organizational commitment, and the Minnesota Satisfaction Questionnaire (MSQ) to measure job satisfaction. This study investigated employees of three five-star hotels in Saudi Arabia. This paper is part of a project that was conducted in three hotels in Saudi Arabia. This study is the first empirical study that focuses on organizational 
commitment and job satisfaction of hotel employees in the Middle East using the three forms of organizational commitment. It contributes to the literature and methodology of both organizational commitment and job satisfaction.

The study concludes that employees are less satisfied and consequently less committed to their employer when they do not feel part of the hotel family; when they believe that their loyalty is too expensive to give to their employers; when they cannot see, feel, or value the benefits provided by their employers; or when they do not believe in leaving the hotel even if it was righteous. The study also concludes that employees are more satisfied and consequently more committed to their employer when they are emotionally attached to and proud of the hotel; when they value their work, when they feel empowered; when they see the need and desire to stay working for the hotel; when they feel guilty leaving the hotel; when they believe that their employer is worth their loyalty; when they believe that they owe a lot to the hotel. The study also concludes that employees may be less satisfied, yet they have an organizational commitment toward their employer. This would occur when employees see the difficulty of leaving the hotel; when they believe they will be negatively affected if they leave the hotel; belief that their obligation toward their employers disables them from leaving. It is concluded that focusing on Affective Organizational Commitment can be very useful in terms of retaining hotel employees. The researcher recommends that hotels managers, particularly Human Resources managers, need to pay attention organizational commitment as means of reducing their employee turnover rate. It is recommended that hotel management teams focus on the emotional side of the employee in order to retain him/her. It is also recommended that hotels management emphasize empowerment to achieve job satisfaction.

\section{References}

- Aiken, L. H., Clarke, S. P., Sloane, D. M., Sochalski, J., and Silber, J. H. (2002). Hospital nurse staffing and patient mortality, nurse burnout, and job dissatisfaction. JAMA: the journal of the American Medical Association, 288(16), 1987-1993.

- Allen, N. J., and Meyer, J. P. (1990). The measurement and antecedents of affective, continuance, and normative commitment to the organization. Journal of Occupational Psychology, 63, 1-18.

- Allen, T. D. (2001). Family-supportive work environments: The role of organizational perceptions. Journal of vocational behavior, 58(3), 414-435.

- Anseel, F., and Lievens, F. (2007). The Long Term Impact of the Feedback Environment on Job Satisfaction: A Field Study in a Belgian Context. Applied Psychology, 56(2), 254-266.

- Bai, B., Brewer, K. P., Sammons, G., \& Swerdlow, S. (2006). Job satisfaction, organizational commitment, and internal service quality: a case study of Las Vegas hotel/casino industry. Journal of Human Resources in Hospitality \& Tourism, 5(2), 37-54.

- Bender, K. A., and Heywood, J. S. (2006). Job satisfaction of the highly educated: The role of gender, academic tenure, and earnings. Scottish Journal of Political Economy, 53(2), 253-279.

- Bender, K. A., Donohue, S. M., and Heywood, J. S. (2005). Job satisfaction and gender segregation. Oxford Economic Papers, 57(3), 479-496.

- Böckerman, P., and Ilmakunnas, P. (2006). Do job disamenities raise wages or ruin job satisfaction?. International Journal of Manpower, 27(3), 290-302.

- Bogler, R. (2002). Two profiles of schoolteachers: a discriminant analysis of job satisfaction. Teaching and Teacher Education, 18(6), 665-673.

- Booth, A. L., and Van Ours, J. C. (2008). Job Satisfaction and Family Happiness: The Part-Time Work Puzzle*. The Economic Journal, 118(526), F77-F99.

- Bozeman, D. P., \& Perrewé, P. L. (2001). The effect of item content overlap on Organizational Commitment Questionnaire-turnover cognitions relationships. Journal of Applied Psychology, 86(1), 161.

- Chen, C. F. (2006). Job satisfaction, organizational commitment, and flight attendants' turnover intentions: A note. Journal of Air Transport Management, 12(5), 274-276.

- Clark, A. E., Kristensen, N., and Westergård-Nielsen, N. (2009). Job Satisfaction and Co-worker Wages: Status or Signal?*. The Economic Journal, 119(536), 430-447.

- Collins, S. (2008). Statutory social workers: Stress, job satisfaction, coping, social support and individual differences. British Journal of Social Work, 38(6), 1173-1193.

- Colquitt, J. A., Conlon, D. E., Wesson, M. J., Porter, C. O., and Ng, K. Y. (2001). Justice at the millennium: a metaanalytic review of 25 years of organizational justice research. Journal of applied psychology, 86(3), 425.

- Cortese, C. G., Colombo, L., and Ghislieri, C. (2010). Determinants of nurses' job satisfaction: the role of work-family conflict, job demand, emotional charge and social support. Journal of nursing management, 18(1), 35-43.

- Cronbach, L. and Shavelson, R. (2004). My Current thoughts on coefficient Alpha and successor Procedures. Educational and Psychological Measurement, 64 (3), 391-418.

- Cummings, G. G., Olson, K., Hayduk, L., Bakker, D., Fitch, M., Green, E., and Conlon, M. (2008). The relationship between nursing leadership and nurses' job satisfaction in Canadian oncology work environments. Journal of nursing management, 16(5), 508-518.

- Currivan, D. B. (2000). The causal order of job satisfaction and organizational commitment in models of employee turnover. Human Resource Management Review, 9(4), 495-524. 
- De Vries, R. E., Van den Hooff, B., and de Ridder, J. A. (2006). Explaining knowledge sharing the role of team communication styles, job satisfaction, and performance beliefs. Communication Research, 33(2), 115-135.

- Demerouti, E., Bakker, A. B., Nachreiner, F., and Schaufeli, W. B. (2000). A model of burnout and life satisfaction amongst nurses. Journal of Advanced Nursing, 32(2), 454-464.

- Evans, L. (1997). Addressing problems of conceptualization and construct validity in researching teachers' job satisfaction. Educational Research, 39(3), 319-331.

- Fairbrother, K., and Warn, J. (2003). Workplace dimensions, stress and job satisfaction. Journal of managerial psychology, 18(1), 8-21.

- Faragher, E. B., Cass, M., and Cooper, C. L. (2005). The relationship between job satisfaction and health: a metaanalysis. Occupational and environmental medicine, 62(2), 105-112.

- Gibbs, J. (2001) 'Maintaining front line workers in child protection: A case for refocusing supervision', Child Abuse Review, 10, pp. 323-35.

- Gittell, J. H., Weinberg, D., Pfefferle, S., and Bishop, C. (2008). Impact of relational coordination on job satisfaction and quality outcomes: a study of nursing homes. Human Resource Management Journal, 18(2), 154-170.

- Godechot, O., and Gurgand, M. (2000). Quand les salariés jugent leur salaire. Economie et statistique, 331(1), 3-24.

- Gunlu, E., Aksarayli, M., \& Perçin, N. S. (2010). Job satisfaction and organizational commitment of hotel managers in Turkey. International Journal of Contemporary Hospitality Management, 22(5), 693-717.

- Heaney, C. A., Israel, B. A., and House, J. S. (1994). Chronic job insecurity among automobile workers: Effects on job satisfaction and health. Social science and medicine, 38(10), 1431-1437.

- Hoogendoorn, W. E., Bongers, P. M., De Vet, H. C. W., Ariens, G. A. M., Van Mechelen, W., and Bouter, L. M. (2002). High physical work load and low job satisfaction increase the risk of sickness absence due to low back pain: results of a prospective cohort study. Occupational and Environmental Medicine, 59(5), 323-328.

- Janssen, O. (2001). Fairness perceptions as a moderator in the curvilinear relationships between job demands, and job performance and job satisfaction. Academy of management journal, 44(5), 1039-1050.

- Janssen, O., and Van Yperen, N. W. (2004). Employees' goal orientations, the quality of leader-member exchange, and the outcomes of job performance and job satisfaction. Academy of management journal, 47(3), 368-384.

- Jones, M. K., Jones, R. J., Latreille, P. L., and Sloane, P. J. (2009). Training, job satisfaction, and workplace performance in Britain: Evidence from WERS 2004. Labour, 23(s1), 139-175.

- Judge, T. A., Heller, D., and Mount, M. K. (2002). Five-factor model of personality and job satisfaction: a metaanalysis. Journal of applied psychology, 87(3), 530.

- Judge, T. A., Thoresen, C. J., Bono, J. E., and Patton, G. K. (2001). The job satisfaction-job performance relationship: A qualitative and quantitative review. Psychological bulletin, 127(3), 376.

- Kim, W. G., Leong, J. K., \& Lee, Y. K. (2005). Effect of service orientation on job satisfaction, organizational commitment, and intention of leaving in a casual dining chain restaurant. International Journal of Hospitality Management, 24(2), 171-193.

- Klassen, R. M., and Chiu, M. M. (2010). Effects on teachers' self-efficacy and job satisfaction: Teacher gender, years of experience, and job stress. Journal of Educational Psychology, 102(3), 741.

- Kristensen, N., and Johansson, E. (2008). New evidence on cross-country differences in job satisfaction using anchoring vignettes. Labour Economics, 15(1), 96-117.

- Lalive, R. (2002). Do wages compensate for workplace amenities? University of Zurich, mimeo.

- Lam, T., Lo, A., \& Chan, J. (2002). New employees' turnover intentions and organizational commitment in the Hong Kong hotel industry. Journal of Hospitality \& Tourism Research, 26(3), 217-234.

- Larrabee J.H., Janney M.A., Ostrow C.L., Withrow M.L., Hobbs G.R. Jr and Burant C. (2003) Predicting registered nurse job satisfaction and intent to leave. Journal of Nursing Administration, 33 (5), 271-283.

- Manojlovich M. and Spence Laschinger H. (2007) The Nursing Work life Model: extending and refining a new theory. Journal of Nursing Management, 15, 256-263.

- Manojlovich, M. (2005). Linking the Practice Environment to Nurses' Job Satisfaction Through Nurse-Physician Communication. Journal of Nursing Scholarship, 37(4), 367-373.

- Nadiri, H., and Tanova, C. (2010). An investigation of the role of justice in turnover intentions, job satisfaction, and organizational citizenship behavior in hospitality industry. International Journal of Hospitality Management, 29(1), 3341.

- Namasivayam, K., \& Zhao, X. (2007). An investigation of the moderating effects of organizational commitment on the relationships between work-family conflict and job satisfaction among hospitality employees in India. Tourism Management, 28(5), 1212-1223.

- Nandi, A., Galea, S., Tracy, M., Ahern, J., Resnick, H., Gershon, R., and Vlahov, D. (2004). Job loss, unemployment, work stress, job satisfaction, and the persistence of posttraumatic stress disorder one year after the September 11 attacks. Journal of Occupational and Environmental Medicine, 46(10), 1057-1064.

- Newbury-Birch, D., and Kamali, F. (2001). Psychological stress, anxiety, depression, job satisfaction, and personality characteristics in preregistration house officers. Postgraduate medical journal, 77(904), 109-111. 
- Ozyurt, A., Hayran, O., and Sur, H. (2006). Predictors of burnout and job satisfaction among Turkish physicians. Qjm, 99(3), 161-169.

- Parker, C. P., Baltes, B. B., Young, S. A., Huff, J. W., Altmann, R. A., Lacost, H. A., and Roberts, J. E. (2003). Relationships between psychological climate perceptions and work outcomes: a meta-analytic review. Journal of Organizational Behavior, 24(4), 389-416.

- Pitts, D. (2009). Diversity management, job satisfaction, and performance: Evidence from US federal agencies. Public Administration Review, 69(2), 328-338.

- Pronovost P., Berenholtz S., Dorman T. et al. (2003) Improving communication in the ICU using daily goals. Journal of Critical Care 18, 71-75.

- Schaufeli, W. B., Bakker, A. B., and Van Rhenen, W. (2009). How changes in job demands and resources predict burnout, work engagement, and sickness absenteeism. Journal of Organizational Behavior, 30(7), 893-917.

- Silva, P. (2006). Effects of disposition on hospitality employee job satisfaction and commitment. International Journal of Contemporary Hospitality Management, 18(4), 317-328.

- Smith, K., Gregory, S. R., \& Cannon, D. (1996). Becoming an employer of choice: assessing commitment in the hospitality workplace. International Journal of Contemporary Hospitality Management, 8(6), 3-9.

- Somech, A., and Drach-Zahavy, A. (2000). Understanding extra-role behavior in schools: The relationships between job satisfaction, sense of efficacy, and teachers' extra-role behavior. Teaching and Teacher Education, 16(5), 649-659.

- Spector, P. E., Allen, T. D., Poelmans, S. A., Lapierre, L. M., Cooper, C. L., MICHAEL, O. D., and WIDERSZALBAZYL, M. A. R. I. A. (2007). Cross-National Differences in Relationships of Work Demands, Job Satisfaction, and Turnover Intentions with Work-Family Conflict. Personnel Psychology, 60(4), 805-835.

- Sveinsdottir, H., Biering, P., and Ramel, A. (2006). Occupational stress, job satisfaction, and working environment among Icelandic nurses: a cross-sectional questionnaire survey. International Journal of Nursing Studies, 43(7), 875889.

- Tzeng, H. M. (2002). The influence of nurses' working motivation and job satisfaction on intention to quit: an empirical investigation in Taiwan. International Journal of Nursing Studies, 39(8), 867-878.

- Um, M.-Y. and Harrison, D. (1998) 'Role stressors, burnout, mediators and job satisfaction: A stress strain outcome model and an empirical test', Social Work Research, 22(2), pp. 110-15

- Wegge, J., Schmidt, K. H., Parkes, C., and Dick, R. (2007). Taking a sickie: Job satisfaction and job involvement as interactive predictors of absenteeism in a public organization. Journal of Occupational and Organizational Psychology, 80(1), 77-89.

- Zangaro, G. A., and Soeken, K. L. (2007). A meta-analysis of studies of nurses' job satisfaction. Research in nursing and Health, 30(4), 445-458. 